\title{
Quantification of Fusarium solani f. sp. phaseoli in Mycorrhizal Bean Plants and Surrounding Mycorrhizosphere Soil Using Real-Time Polymerase Chain Reaction and Direct Isolations on Selective Media
}

\author{
M. Filion, M. St-Arnaud, and S. H. Jabaji-Hare
}

First and third authors: Department of Plant Science, McGill University, Macdonald Campus, 21, 111 Lakeshore, Raymond Bldg, Ste-Annede-Bellevue, QC, Canada, H9X 3V9; and second author: Institut de recherche en biologie végétale, Université de Montréal and Jardin botanique de Montréal, 4101 Sherbrooke Street East, Montréal, QC, Canada, H1X 2B2. Accepted for publication 17 September 2002.

\section{ABSTRACT}

Filion, M., St-Arnaud, M., and Jabaji-Hare, S. H. 2003. Quantification of Fusarium solani f. sp. phaseoli in mycorrhizal bean plants and surrounding mycorrhizosphere soil using real-time polymerase chain reaction and direct isolations on selective media. Phytopathology 93:229-235.

The capacity of the arbuscular mycorrhizal fungus Glomus intraradices in reducing the presence of Fusarium solani f. sp. phaseoli in bean plants and the surrounding mycorrhizosphere soil was evaluated in a compartmentalized experimental system. Quantification of the pathogen and the symbiont in plant tissues, the soil regions of the mycorrhizosphere (rhizosphere and mycosphere), and the bulk soil was accomplished using specific polymerase chain reaction (PCR) primers in realtime PCR assays, culture-dependant methods, and microscopic determi- nation techniques. Nonmycorrhizal bean plants infected with the pathogen had distinctive Fusarium root rot symptoms, while infected plants previously colonized by $G$. intraradices remained healthy. The amount of F. solani f. sp. phaseoli genomic DNA was significantly reduced in mycorrhizal bean plants and in each mycorrhizosphere soil compartment. The presence of $G$. intraradices in the mycorrhizosphere was not significantly modified, although the mycorrhizal colonization of roots was slightly increased in the presence of the pathogen. The results suggest that the reduced presence of Fusarium as well as root rot symptoms are caused by biotic and/or abiotic modifications of the mycorrhizosphere as a result of colonization with $G$. intraradices.

Additional keywords: LightCycler, Phaseolus vulgaris, SYBR Green.
Roots of plants support the growth of a complex of microorganisms that in concert can have a profound effect on the life cycle and survival of the plant. Among these organisms, arbuscular mycorrhizal fungi (AMF) are known to improve the nutritional status of their host (42) and provoke alterations in the host's physiology (29) and exudation from roots $(5,39)$. Following colonization, AMF extend their extraradical hyphae out of the root system and explore the surrounding soil, altering its physio/ chemical properties $(4,48)$ and causing quantitative and qualitative changes in the soil microbial population composition $(1,2,14$, $38,44)$. Together, the rhizosphere, which is composed of the soil portion surrounding the roots colonized or not by AMF, and the mycosphere, which is composed of the soil surrounding the extraradical mycelium of AMF that extend to a certain distance from the rhizosphere, constitute the mycorrhizosphere, a complex environment which is directly under the influence of the mycorrhizal symbiosis (28).

There is accumulating evidence that AMF can reduce disease incidence and propagule number of several soilborne pathogens including Aphanomyces, Fusarium, Phytophthora, Pythium, and Verticillium species in the plant and mycorrhizosphere $(7,8,22,30$, $32,40,43,46)$. Although the mechanisms implicated are still not well characterized, direct and indirect interactions between AMF and pathogens have been put forward as a plausible hypothesis to explain the role of AMF in biological control of root diseases $(3,24,44)$.

Fusarium root rot of beans (Phaseolus vulgaris L.), caused by Fusarium solani (Mart.) Sacc. f. sp. phaseoli (Burkholder) W.C.

Corresponding author: S. H. Jabaji-Hare; E-mail address: suha.jabaji-hare@ mcgill.ca

Publication no. P-2002-1121-01R

(c) 2003 The American Phytopathological Society
Snyder \& N.H. Hans, is a model system that has been intensively studied by plant pathologists for more than three decades (36). The pathogen is known to be very persistent in soil and capable of surviving in infested fields almost indefinitely (6). Although little damage is usually observed in unstressed plants, high disease incidence has been reported under conditions of reduced root growth caused by drought or oxygen stresses (34). Reduction of Fusarium root rot of beans as a result of arbuscular mycorrhizal colonization has been suggested by few studies $(18,21,35)$. The results of these studies showed root rot symptoms, number of infection sites on bean roots, and propagule number of $F$. solani $\mathrm{f}$. sp. phaseoli in the mycorrhizosphere were reduced in presence of the AMF Glomus macrocarpum $(18,35)$ or G. mosseae (21). Direct interactions such as competition between the symbiont and the pathogen for infection sites (35), or indirect interactions such as alteration of root exudation and/or of the mycorrhizosphere microbial community (21) were proposed as mechanisms favoring this reduction, although direct evidence to support these hypotheses is lacking. It is evident from these studies that the exact role of AMF in reducing Fusarium root rot of beans is not clear and requires more research.

Based on the limited knowledge available on AMF interactions with Fusarium root rot of beans, the general objective of this study was to investigate if the AMF $G$. intraradices can protect bean plants against root rot caused by $F$. solani f. sp. phaseoli, and whether this protection is mediated through direct and/or indirect interactions that occur in the mycorrhizosphere. To achieve this objective, an experimental microcosm compartmentalized system that mimics the different soil regions of the mycorrhizosphere, allows monitoring of the AMF and the pathogen populations, and discriminates between direct and indirect interactions occurring in the different soil zones of this environment was used (15). Quantification of the pathogen and the symbiont in the plant and 
soil regions of the mycorrhizosphere was performed using two different approaches: (i) cultivation-dependent or morphologicalbased methods (i.e., CFU, percent root colonization, and hyphal length determination); and (ii) cultivation-independent or molecular methods (i.e., real-time PCR quantification).

\section{MATERIALS AND METHODS}

Experimental unit. A compartmentalized experimental unit (15) made of a central seedling compartment connected by filters of different pore sizes to three lateral compartments which mimics the two natural ecological soil zones of the mycorrhizosphere: (i) the rhizosphere compartment that contains plant roots colonized or not by AMF, which is a direct extension of the central seedling compartment; (ii) the mycosphere compartment that contains AMF only and no roots; or (iii) the bulk soil (control) compartment that contains no roots or AMF but is accessible to diffusion of soluble molecules was used to study the interaction between the AMF $G$. intraradices Schenck \& Smith (DAOM 181602) and the plant pathogen $F$. solani sp. phaseoli (ATCC 60860).

Fungal inocula. $G$. intraradices was grown and maintained on transformed carrot (Daucus carota L.) roots under in vitro conditions for 8 to 12 weeks at $26^{\circ} \mathrm{C}(15,45)$. Axenically produced spores were extracted from cultures by solubilization of the medium in $10 \mathrm{mM}$ sodium citrate buffer $\left(\mathrm{pH} \mathrm{6.0)}\right.$ at $30^{\circ} \mathrm{C}(13)$. Spores were collected by vacuum filtration using $20 \mu \mathrm{m}$ nylon filters (Fisher Scientific Ltd., Nepean, ON, Canada) and resuspended in sterile distilled water. Spores were freeze-dried for $48 \mathrm{~h}$, ground in liquid nitrogen to produce a fine powder, and stored at $-80^{\circ} \mathrm{C}$ until required for DNA extraction, or their number was adjusted with sterile distilled water to $2.5 \times 10^{3}$ spores $\mathrm{ml}^{-1}$. These spores were cold-treated for 21 days at $4^{\circ} \mathrm{C}$ prior to use.

Production of macroconidia of $F$. solani f. sp. phaseoli for inoculation experiments was obtained by transferring one agar plug ( $8 \mathrm{~mm}$ diameter), obtained from a 1-week-old colony grown on potato dextrose agar (PDA), on potato-carrot medium that contained per liter, each of the following: filtered infusion extracted from $20 \mathrm{~g}$ of carrots and potatoes boiled in 1 liter of water, and $20 \mathrm{~g}$ of Bacto-agar. Cultures were incubated at $22^{\circ} \mathrm{C}$ under fluorescent and black lights for 10 days. To obtain a conidial suspension, the surface of the culture plates was flooded with $2 \mathrm{ml}$ of sterile distilled water, agitated for $30 \mathrm{~s}$, serially diluted, and adjusted to $4 \times 10^{4}$ conidia $\mathrm{ml}^{-1}$ using a hemacytometer. For genomic DNA extraction, eight agar plugs (8-mm diameter) obtained from 2-week-old cultures of $F$. solani $\mathrm{f}$. sp. phaseoli were used to inoculate 250-ml Erlenmeyer flasks containing $70 \mathrm{ml}$ of potato dextrose broth. Cultures were incubated at room temperature $\left(22^{\circ} \mathrm{C}\right)$ for 7 days under low agitation $(100 \mathrm{rpm})$. Mycelial mats were collected by filtration using Whatman No. 1 filter papers, freeze dried for $48 \mathrm{~h}$, ground in liquid nitrogen to produce a fine powder, and stored at $-80^{\circ} \mathrm{C}$ until required for DNA extraction.

Experimental set-up. The complete experiment was repeated twice (trial 1 and 2), and the experimental set up of each trial consisted of a randomized complete block design with three blocks and four $G$. intraradices/F. solani f. sp. phaseoli inoculation treatments randomized among the blocks. The treatments were: (i) inoculated with $G$. intraradices and $F$. solani f. sp. phaseoli; (ii) inoculated with $G$. intraradices only; (iii) inoculated with $F$. solani f. sp. phaseoli only; and (iv) uninoculated controls.

Each experimental microcosm unit received $50 \mathrm{ml}$ per seedling compartment and $8 \mathrm{ml}$ per lateral compartment of a soil mix consisting of field soil ( $3 \mathrm{~mm}$ sieved), Turface, peat (4 mm sieved), and perlite $(1: 1: 1: 1 \mathrm{vol} / \mathrm{vol})$. The soil mix $(70 \%$ sand, $19 \%$ silt, $11 \%$ clay, $8.0 \%$ organic matter, $170 \mathrm{mg} \mathrm{kg}^{-1}$ of $\mathrm{P}, 362 \mathrm{mg} \mathrm{kg}^{-1}$ of $\mathrm{K}, 2,813 \mathrm{mg} \mathrm{kg}^{-1}$ of $\mathrm{Ca}, 330 \mathrm{mg} \mathrm{kg}{ }^{-1}$ of $\mathrm{Mg}, \mathrm{pH} 5.29$ ) was autoclaved for $60 \mathrm{~min}$ at $121^{\circ} \mathrm{C}$ three times on three consecutive days before use. Three days prior to planting, all experimental units received $8 \mathrm{ml}(5 \mathrm{ml}$ in the seedling compartment and $1 \mathrm{ml}$ per lateral compartment) of a soil filtrate that was prepared from a suspension of $50 \mathrm{~g}$ of fresh field soil in 1 liter of distilled water for $10 \mathrm{~min}$ and filtered through a Whatman No. 1 filter paper to reintroduce soil microflora other than indigenous AMF.

Growth conditions and inoculation with $G$. intraradices. The seedling compartment of each experimental unit with the mycorrhizal treatment was inoculated at planting with $2.5 \times 10^{3}$ spores of $G$. intraradices delivered in a $1-\mathrm{ml}$ volume, while the experimental units without the mycorrhizal treatment received $1 \mathrm{ml}$ of distilled water. The inoculum was mixed with the soil. Beans cv. UT15 Contender seeds (Stokes Seeds Ltd., Ste-Catherine, ON, Canada) were surface sterilized in $30 \% \mathrm{H}_{2} \mathrm{O}_{2}$ for $5 \mathrm{~min}$, rinsed four times with sterile distilled water, and pregerminated for $72 \mathrm{~h}$ on filter papers soaked with sterile tap water. At planting, the experimental units were watered to maximum retention capacity with distilled water and one pregerminated bean seed was sown in the seedling compartment of each experimental unit. The units were maintained in a growth chamber at 21 and $18^{\circ} \mathrm{C}$ (day/night) with $80 \%$ relative humidity. Fluorescent lamps were operated for $14 \mathrm{~h}$ per day and generated a photon flux of $187 \mu \mathrm{mol} \mathrm{m} \mathrm{m}^{-2} \cdot \mathrm{s}^{-1}$ PAR. The central compartment of each experimental unit was watered daily with $10 \mathrm{ml}$ of distilled water and also received twice a week after 14 days of growth, $5 \mathrm{ml}$ of a modified Long Ashton solution $\left(\mathrm{KNO}_{3}, 750 \mathrm{mg}\right.$ liter ${ }^{-1} ; \mathrm{Ca}\left(\mathrm{NO}_{3}\right)_{2} \cdot 4 \mathrm{H}_{2} \mathrm{O}, 950 \mathrm{mg}$ liter ${ }^{-1}$; $\mathrm{NaH}_{2} \mathrm{PO}_{4} \cdot \mathrm{H}_{2} \mathrm{O}, 200 \mathrm{mg} \operatorname{liter}^{-1} ; \mathrm{MgSO}_{4} \cdot 7 \mathrm{H}_{2} \mathrm{O}, 500 \mathrm{mg} \operatorname{liter}^{-1}$; $\mathrm{MnSO}_{4} \cdot \mathrm{H}_{2} \mathrm{O}, \quad 1.7 \mu \mathrm{g}$ liter ${ }^{-1} ; \mathrm{CuSO}_{4} \cdot 5 \mathrm{H}_{2} \mathrm{O}, 0.25 \mu \mathrm{g}$ liter $^{-1}$; $\mathrm{ZnSO}_{4} \cdot 7 \mathrm{H}_{2} \mathrm{O}, 0.3 \mu$ liter $^{-1} ; \mathrm{H}_{3} \mathrm{BO}_{3}, 3 \mu$ liter $^{-1} ; \mathrm{NaCl}, 5 \mu$ liter $^{-1}$; $\left(\mathrm{NH}_{4}\right)_{6} \mathrm{Mo}_{7} \mathrm{O}_{24} \cdot 4 \mathrm{H}_{2} \mathrm{O}, 40 \mu$ liter $^{-1}$; EDTA-Fe, $41 \mathrm{mg} \mathrm{liter}^{-1}$ ) until harvesting (43).

Infection with $\boldsymbol{F}$. solani f. sp. phaseoli. After 28 days of growth, the seedling compartment of each experimental unit with the Fusarium treatment was inoculated with $5 \mathrm{ml}$ of a $F$. solani $\mathrm{f}$. sp. phaseoli conidial suspension adjusted to a final concentration of $4 \times 10^{4}$ conidia $\mathrm{ml}^{-1}$, while each lateral compartment was injected through the cap septum using a syringe with $1 \mathrm{ml}$ of the same conidial suspension. The experimental units, having no $F$. solani $\mathrm{f}$. sp. phaseoli, were inoculated with $5 \mathrm{ml}$ of distilled water in the seedling compartment and $1 \mathrm{ml}$ in each lateral compartment. Plants were harvested 6 days after pathogen inoculation.

CFU and hyphal length determination. At harvest, all experimental units were dismantled, and the soil was collected from each lateral compartment of each replicate and independently homogenized. A portion of the soil ( $0.5 \mathrm{~g}$ per replicate) from each lateral compartment was directly used to determine from suitable serial dilutions the CFU of $F$. solani f. sp. phaseoli per gram of soil using the Nash-Snyder medium supplemented with benomyl (20). The remaining soil was freeze-dried for 2 days and served for genomic DNA extraction (see below) and hyphal length measurement after aqueous extraction, filtration, and staining according to Jakobsen et al. (23). Total fungal hyphal length, including $G$. intraradices, was calculated based on intersections between acid fuchsin-stained hyphae and an ocular gridline of 25 view fields at $\times 200$ magnification (maximum resolution of approximately 10 microns) using Newman's formula (37) and expressed as $\mathrm{m} \mathrm{g}^{-1}$ of soil for each lateral soil compartment.

Estimation of mycorrhizal colonization and pathogen infection. Bean plants with their roots were removed from the seedling compartments and washed under tap water. Necrotic lesions on the roots and hypocotyl was rated on a scale of 0 to 5 (33), where $0=$ no disease symptoms, $1=$ slightly brown or $<50 \%$ surface discoloration of the hypocotyl, firm upon pressure from thumb and forefinger, and slight root pruning, $2=$ as 1 but $>50 \%$ surface discoloration, 3 = discolored hypocotyl and roots collapsing under considerable pressure and extensive root pruning, $4=$ darkly discolored hypocotyl and roots completely collapsed or collapsing easily under pressure and severe root pruning, and $5=$ dead or dying plant. 
A subsample of roots $(100 \mathrm{mg})$ was cut into $1-\mathrm{cm}$ sections, cleared in $10 \% \mathrm{KOH}$, and after staining with acid fuchsin (25) the percentage of root length colonized by hyphae, arbuscules, and vesicles of $G$. intraradices was determined using the gridline intersect method (17). The remaining roots were freeze-dried for 2 days and ground in liquid nitrogen prior to DNA extraction. Dry mass of shoots of each plant was determined after drying at $70^{\circ} \mathrm{C}$ for $48 \mathrm{~h}$.

DNA extraction. Fungal genomic DNA was isolated from $20 \mathrm{mg}$ of freeze-dried spores or mycelia according to Lee and Taylor (26), resuspended in $70 \mu \mathrm{l}$ of sterile distilled water, and treated with $2 \mu \mathrm{l}$ of RNAse at $37^{\circ} \mathrm{C}$ for $30 \mathrm{~min}$. Purified DNA extracted from spores of $G$. intraradices and mycelia of $F$. solani $\mathrm{f}$. sp. phaseoli pure cultures was quantified spectrophotometrically and by comparison to DNA standards using agarose gel electrophoresis.

Total genomic DNA was extracted from $100 \mathrm{mg}$ of freeze-dried powdered roots using the DNeasy plant DNA extraction kit (Qiagen Inc., Mississauga, ON, Canada). The DNA was eluted twice in $50 \mu \mathrm{l}$ of buffer $\mathrm{AE}$ and both elutions were combined and stored at $-20^{\circ} \mathrm{C}$ until real-time PCR amplification (described below). Total soil genomic DNA was extracted from freeze-dried soil using the MoBio Soil DNA isolation kit (MoBio Laboratories, Inc., Solana Beach, CA) with the following modifications: $200 \mathrm{mg}$ of freeze-dried soil was used instead of $250 \mathrm{mg}$ with a FastPrep apparatus (Thermo Savant, Holbrook, NY) at speed level 4 for $15 \mathrm{~s}$. The DNA was resuspended in $50 \mu \mathrm{l}$ of solution S5 (MoBio Laboratories, Inc.) and stored at $-20^{\circ} \mathrm{C}$ until real-time $\mathrm{PCR}$ amplification.

PCR primers. A set of specific PCR primer pairs was used to amplify $G$. intraradices or $F$. solani f. sp. phaseoli DNA. For $G$. intraradices, the GIfor (5'-CCTGCTAAATAGCTAGGCCTAAC$3^{\prime}$ ) and GIrev (5'-CTCCGAATCTCAATCCGAAGGC-3') oligonucleotides flanking a 362-bp DNA fragment located near the $3^{\prime}$ end of the SSU rRNA gene were used (16). The primer pair Effp-1 (5'-AACCCCGCCCGAGGACTCA-3') and Effp-2 (5'-AGACATGAGCGATGAGAGGCA-3') were designed (K. O'Donnell, personal communication) to generate a DNA product of $562 \mathrm{bp}$ from the $F$. solani $\mathrm{f}$. sp. phaseoli translation elongation factor 1 alpha gene. All primer sequences were submitted to GenBank (National Resource for Molecular Biology Information) and Basic Local Alignment Search Tool (BLAST) was used to confirm the absence of significant homology with other known DNA sequences. The primers were commercially synthesized (Alpha DNA, Montréal, QC, Canada). As a positive control, DNA samples were amplified with the universal primers NS1/NS2 that recognize a 555-bp DNA fragment from the $18 \mathrm{~S}$ fungal ribosomal gene (47). This control was performed to ensure the quality of the extracted DNA, to test for the presence of fungal DNA in the soil, and to minimize the risk of obtaining false-negative results.

Standard curves. Standard curves based on threshold cycles $\left(\mathrm{C}_{\mathrm{t}}\right)$ for 10-fold dilution series of pure DNA from $G$. intraradices or $F$. solani f. sp. phaseoli (in $\mathrm{ng}^{-1} \mathrm{l}^{-1}: 2.5 \times 10^{1}, 2.5 \times 10^{0}, 2.5 \times$ $10^{-1}, 2.5 \times 10^{-2}$, and $2.5 \times 10^{-3}$ ) were constructed for each fungus. $\mathrm{C}_{\mathrm{t}}$ values were calculated by the LightCycler software program version 3.5 (Roche Diagnostics, Laval, QC, Canada) to indicate significant fluorescence signals rising above background during the early cycles of the exponentially growing phase of the PCR amplification process. A standard curve was obtained by plotting the $C_{t}$ value, which is defined by the crossing cycle number or crossing point versus the logarithm of the concentration of each 10-fold dilution series of fungal DNA. As $C_{t}$ values may slightly vary between experiments, we included parallel runs of three separate dilution series of pure standard DNA in all PCR amplification runs.

Real-time PCR amplification. Real-time PCR amplifications on total genomic DNA extracted from soil and roots were carried out in glass capillaries (Roche Diagnostics) in a total volume of $20 \mu \mathrm{l}$ using a LightCycler (Roche Diagnostics) and SYBR Green I (Roche Diagnostics) as the reporter fluorescent dye. The reaction mixture contained $2 \mu \mathrm{l}$ of undiluted DNA template extracted from soil or roots, $1.2 \mu \mathrm{l}$ of $25 \mathrm{mM} \mathrm{MgCl}, 2.0 \mu \mathrm{l}$ of each primer $(5 \mu \mathrm{m}), 2.0 \mu \mathrm{l}$ of the FastStart DNA Master SYBR Green I (Roche Diagnostics). Control reactions contained the same mixtures with $2.0 \mu \mathrm{l}$ of sterile water replacing the DNA template. The thermal cycling conditions for $F$. solani f. sp. phaseoli DNA template amplification were an initial denaturation at $95^{\circ} \mathrm{C}$ for $10 \mathrm{~min}$ followed by 55 cycles at $95^{\circ} \mathrm{C}$ for $0 \mathrm{~s}, 72^{\circ} \mathrm{C}$ for $28 \mathrm{~s}$, and $86^{\circ} \mathrm{C}$ for $1 \mathrm{~s}$ using a slope of $20^{\circ} \mathrm{C}$ per s. A melting curve temperature profile was obtained by programming the LightCycler for 1 cycle at $95^{\circ} \mathrm{C}$ for $0 \mathrm{~s}$ and $50^{\circ} \mathrm{C}$ for $60 \mathrm{~s}$ using a slope of $20^{\circ} \mathrm{C}$ per s, followed by $95^{\circ} \mathrm{C}$ for $0 \mathrm{~s}$ using a slope of $0.1^{\circ} \mathrm{C}$ per s. The conditions for $G$. intraradices DNA template amplification were initial denaturation at $95^{\circ} \mathrm{C}$ for $10 \mathrm{~min}$ followed by 70 cycles at $95^{\circ} \mathrm{C}$ for $5 \mathrm{~s}, 69^{\circ} \mathrm{C}$ for $5 \mathrm{~s}, 72^{\circ} \mathrm{C}$ for $15 \mathrm{~s}$, and $83^{\circ} \mathrm{C}$ for $1 \mathrm{~s}$ using a slope of $20^{\circ} \mathrm{C}$ per s. A melting curve temperature profile was obtained by programming the LightCycler for 1 cycle at $95^{\circ} \mathrm{C}$ for $0 \mathrm{~s}$ and $70^{\circ} \mathrm{C}$ for $30 \mathrm{~s}$ using a slope of $20^{\circ} \mathrm{C}$ per s, followed by $95^{\circ} \mathrm{C}$ for $0 \mathrm{~s}$ using a slope of $0.1^{\circ} \mathrm{C}$ per s.

Post-PCR analysis. For each fungus, quantification was performed by on-line monitoring for assessment of the exact $C_{t}$ value at which the log-linear phase could be distinguished from the background. The concentrations of fungal DNA in experimental treatments were calculated by comparing $\mathrm{C}_{\mathrm{t}}$ values to the crossing point values of the linear regression line of the standard curve.

Statistical analyses. Analyses were done using correlation and general linear model procedures of the SAS statistical software (SAS Institute Inc., Cary, NC). The relation between $\mathrm{C}_{\mathrm{t}}$ values and fungal DNA concentration was analyzed by correlation analyses. $G$. intraradices and $F$. solani f. sp. phaseoli genomic DNA quantification from bean plants and soil, percentage of root length colonized by the mycorrhizal fungus, percentage of root length harboring $G$. intraradices vesicles, percentage of root length harboring $G$. intraradices arbuscules, shoot dry weight, hyphal

TABLE 1. Effect of Glomus intraradices and Fusarium solani f. sp. phaseoli inoculation treatments on Fusarium root rot disease severity, percent arbuscular mycorrhizal fungi (AMF) root colonization, and shoot dry weight of beans

\begin{tabular}{lccccc}
\hline Treatment $^{\mathrm{x}}$ & Disease severity & Shoot dry weight $(\mathrm{g})$ & AMF colonization $(\%)$ & Vesicles $(\%)$ & Arbuscules $(\%)$ \\
\hline Glo+ Fus+ & 0 & $1.16 \pm 0.05 \mathrm{a}^{\mathrm{z}}$ & $92.7 \pm 0.7 \mathrm{a}$ & $52.0 \pm 4.6 \mathrm{a}$ & $26.7 \pm 6.4 \mathrm{a}$ \\
Glo+ Fus- & 0 & $1.25 \pm 0.10 \mathrm{a}$ & $86.7 \pm 0.7 \mathrm{~b}$ & $44.0 \pm 3.1 \mathrm{a}$ & $28.7 \pm 3.5 \mathrm{a}$ \\
Glo- Fus+ & 1 & $1.21 \pm 0.04 \mathrm{a}$ & $\ldots$ & $\ldots$ & $\ldots$ \\
Glo- Fus- & 0 & $1.12 \pm 0.11 \mathrm{a}$ & $\ldots$ & $\ldots$ & $\ldots$ \\
\hline
\end{tabular}

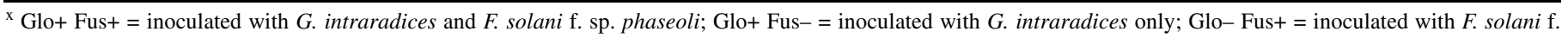
sp. phaseoli only; and Glo- Fus- = uninoculated controls.

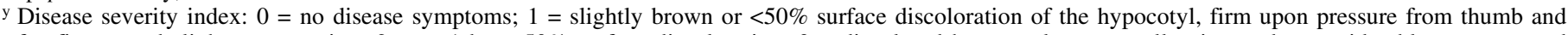
forefinger, and slight root pruning; $2=$ as 1 but $>50 \%$ surface discoloration; $3=$ discolored hypocotyls, roots collapsing under considerable pressure, and extensive root pruning; 4 = darkly discolored hypocotyls, roots completely collapsed or collapsing easily under pressure, and severe root pruning; 5 = dead or dying plant.

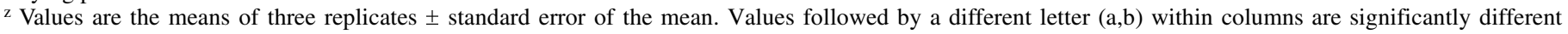
using Tukey's studentized range test $(P<0.05)$. 
length in soil samples, and $F$. solani f. sp. phaseoli CFU were all submitted to analysis of variance (ANOVA). Rank or log transformations (27) were performed when needed to meet the ANOVA requirements. A posteriori comparison between treatments was done by Tukey's studentized range test. Similar results of comparable magnitude were obtained for the two trials $(P<0.05)$, and hence, the results of trial 2 are presented.

\section{RESULTS}

All nonmycorrhizal bean seedlings grown in soil amended with a conidial suspension of $F$. solani $\mathrm{f}$. sp. phaseoli had red lesions on hypocotyls and tap roots characteristically distinctive of Fusarium root rot and disease severity rating of 1.0. In contrast, all mycorrhizal plants infected with the pathogen and noninfected controls showed no symptoms (Table 1).

The use of standard curves based on known concentrations of DNA makes it theoretically possible to quantify DNA from any source. In this study, standard curves were constructed using concentrations ranging from $2.5 \times 10^{1}$ to $2.5 \times 10^{-3} \mathrm{ng}$ for $F$. solani $\mathrm{f}$. sp. phaseoli DNA and $2.5 \times 10^{0}$ to $2.5 \times 10^{-3}$ for G. intraradices DNA. Quantification showed a linear relation $\left(r^{2}=0.999\right)$ between log values of fungal genomic DNA and real-time PCR threshold cycles (threshold fluorescence signal of 0.2 for $F$. solani f. sp. phaseoli and 0.1 for $G$. intraradices) over the range of DNA concentrations examined (Fig. 1).

\section{A}

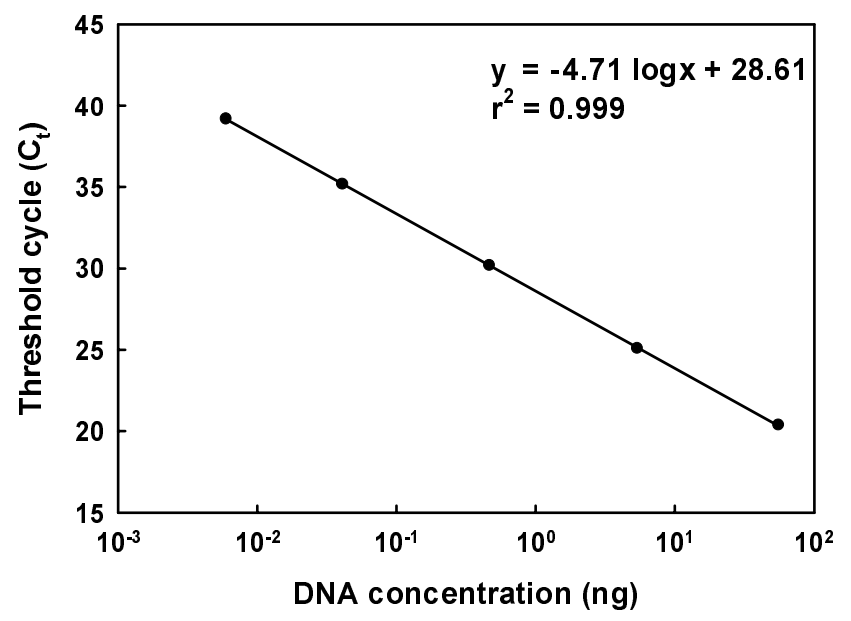

B

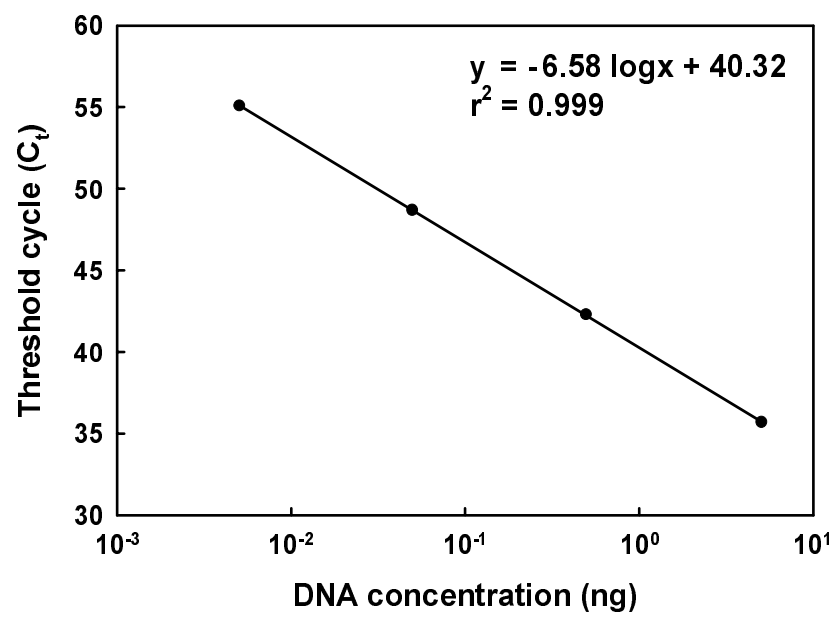

Fig. 1. Standard curves obtained by plotting the genomic DNA concentration of A, Fusarium solani f. sp. phaseoli genomic DNA and $\mathbf{B}$, Glomus intraradices versus cycle number required to elevate the fluorescence signal above the threshold ( 0.2 for $\mathbf{A}$ and 0.1 for $\mathbf{B})$.
The presence of fungal DNA in the plant and the soil was confirmed using primer set NS1/NS2 binding to a portion of the $18 \mathrm{~S}$ fungal ribosomal gene (data not shown). PCR assays using oligonucleotide primer pairs Effp-1/Effp-2 for $F$. solani $\mathrm{f}$. sp. phaseoli and GIfor/GIrev for $G$. intraradices detected the respective expected amplicons of $562 \mathrm{bp}$ and $362 \mathrm{bp}$ from DNA extracted from plant and soil samples, confirming the presence of either fungus (data not shown). No amplification product was obtained from uninoculated controls or treatments without the pathogen or the AMF (Figs. 2 and 3), indicating that the primer pair designed for either fungus did not cross react with nontarget DNA.

The amount of $F$. solani $\mathrm{f}$. sp. phaseoli genomic DNA detected in roots of infected mycorrhizal bean seedlings was substantially and significantly lower $(P<0.01)$ than that of nonmycorrhizal infected bean seedlings (Fig. 2A). Contrarily, the amount of $G$. intraradices DNA detected in mycorrhizal roots infected with the pathogen was similar $(P=0.157)$ to that of mycorrhizal noninfected roots (Fig. 2B).

The percent root length colonized by $G$. intraradices was significantly increased $(P<0.05)$ in plants infected with $F$. solani f. sp. phaseoli, as compared with mycorrhizal bean seedlings not inoculated with Fusarium (Table 1). However, there was no sig-

A

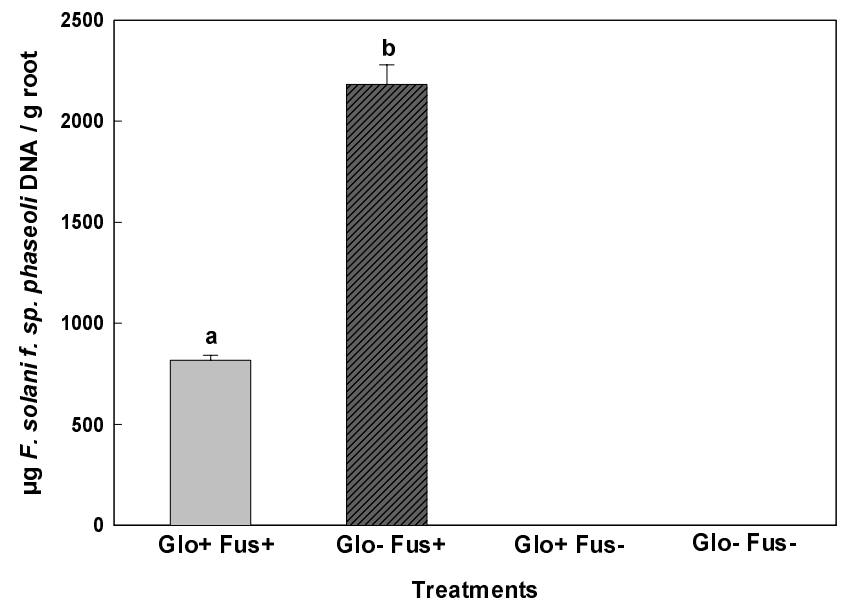

B

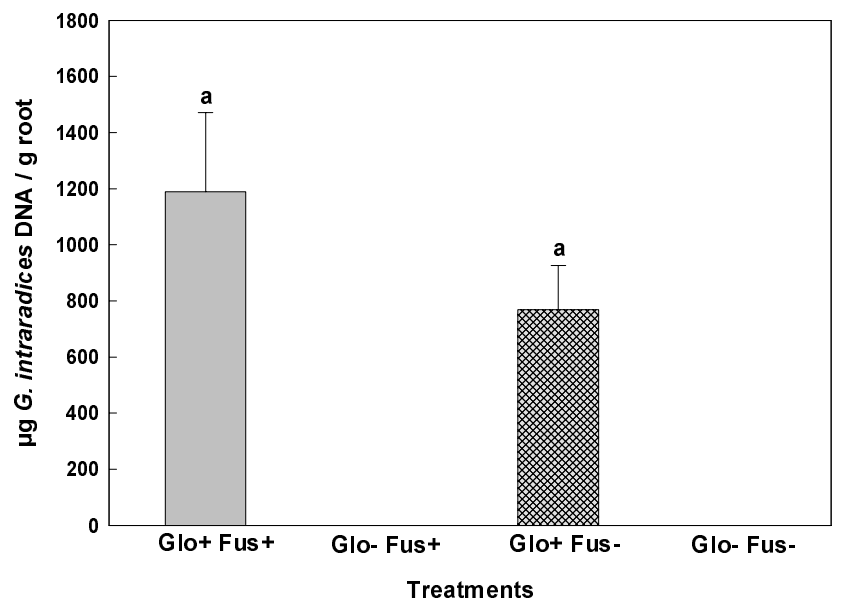

Fig. 2. A, Effect of Glomus intraradices and Fusarium solani f. sp. phaseoli inoculation treatments on $F$. solani f. sp. phaseoli genomic DNA detected in bean roots using real-time PCR. B, Effect of $G$. intraradices and $F$. solani $\mathrm{f}$. sp. phaseoli inoculation treatments on $G$. intraradices genomic DNA detected in bean roots using real-time PCR. Treatments are: Glo+ Fus+ $=$ inoculated with $G$. intraradices and $F$. solani f. sp. phaseoli; Glo+ Fus- = inoculated with $G$. intraradices only; Glo- Fus $+=$ inoculated with $F$. solani f. sp. phaseoli only; and Glo- Fus- = uninoculated controls. Values are the means of three replicates. Error bars represent standard error of the mean. 
nificant difference in the percent number of arbuscules and vesicles per root length between these two treatments (Table 1), although the number of vesicles in mycorrhizal and infected seedlings was slightly higher $(P=0.057)$. Mycorrhizal or pathogenic inoculation did not modify the shoot dry weight of plants and no interaction was found between treatments (Table 1).

The presence and amount of $F$. solani $\mathrm{f}$. sp. phaseoli in the soil of the compartments was evaluated by the number of CFU per gram of soil (Table 2) and the amount of DNA detected by realtime PCR (Fig. 3A). Both methods indicated that $F$. solani f. sp. phaseoli was detected in all three soil compartments of pathogeninoculated plants. Within mycorrhizal inoculation treatments, the number of CFU was similar in the soil of all three soil compartments $(P=0.176$; Table 2$)$ and was not affected by mycorrhizal inoculation. However, the amount of $F$. solani $\mathrm{f}$. sp. phaseoli DNA estimated was significantly reduced $(P<0.05)$ in the $G$. intraradices-inoculated treatment as compared to the nonmycorrhizal but pathogen-infected plants (Fig. 3A). No CFU (Table 2) or PCR (Fig. 3A) product was obtained for F. solani f. sp. phaseoli from soil not inoculated with the pathogen.

\section{A}

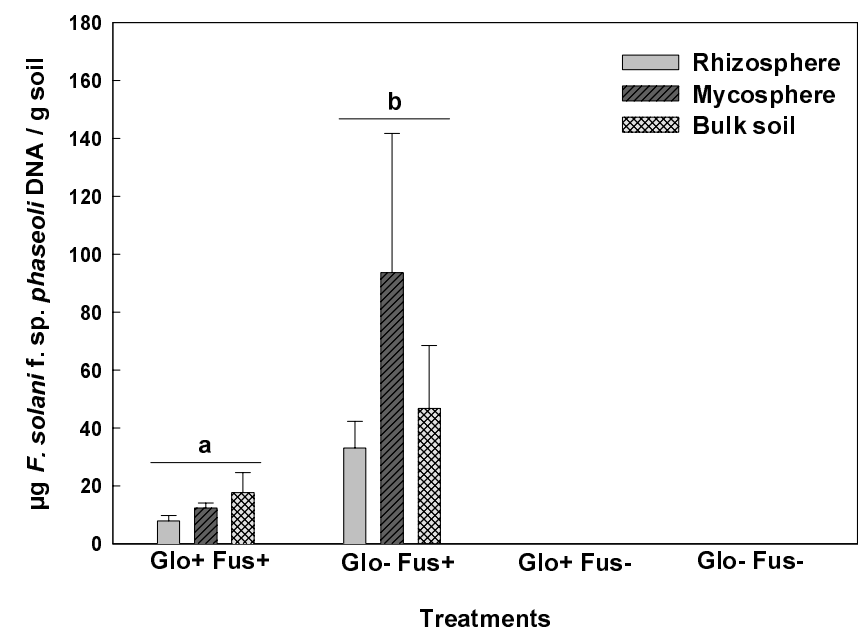

B

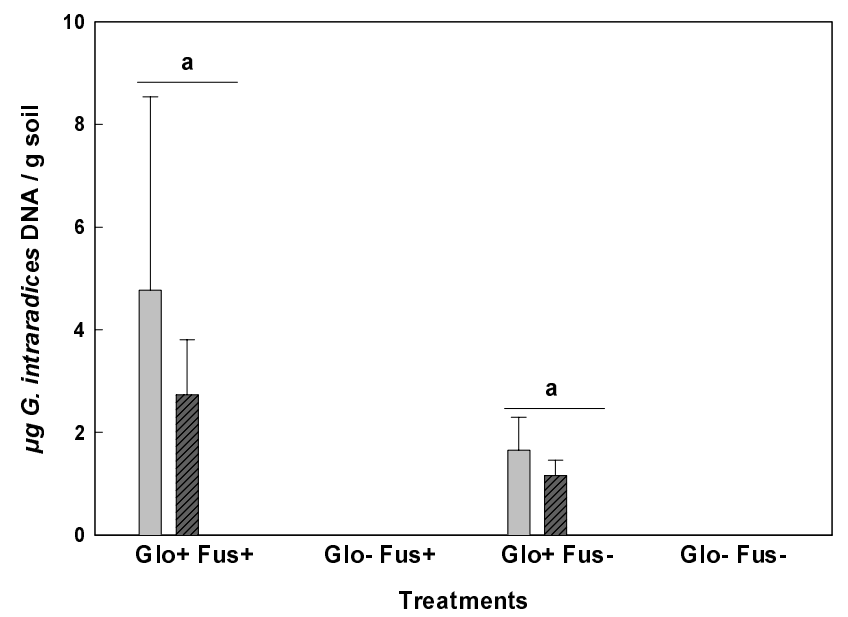

Fig. 3. A, Effect of Glomus intraradices and Fusarium solani f. sp. phaseoli inoculation treatments on $F$. solani f. sp. phaseoli genomic DNA detected in the soil compartments using real-time PCR. B, Effect of $G$. intraradices and $F$. solani f. sp. phaseoli inoculation treatments on $G$. intraradices genomic DNA detected in the soil compartments using real-time PCR. Treatments are: Glo+ Fus+ $=$ inoculated with $G$. intraradices and $F$. solani f. sp. phaseoli; Glo+ Fus- $=$ inoculated with $G$. intraradices only; Glo- Fus+ = inoculated with $F$. solani f. sp. phaseoli only; and Glo- Fus- = uninoculated controls. Values are the means of three replicates. Error bars represent standard error of the mean.
Using the GIfor/GIrev primer pair, the presence of $G$. intraradices DNA was confirmed only in the mycosphere and the rhizosphere soils (Fig. 3B). Genomic DNA of G. intraradices in the soil showed that the mycorrhizal fungus mycelium was not quantitatively modified by the presence of $F$. solani f. sp. phaseoli $(P=0.202)$ or by the presence of the roots $(P=0.419$; Fig. 3B $)$.

Length of hyphae extracted from the soil was significantly affected by mycorrhizal inoculation $(P=0.015)$ and compartment type $(P=0.029)$, and a significant interaction $(P=0.007)$ was found between these treatments. Hyphal length values were significantly higher $(P<0.05)$ in the soil of experimental units colonized by $G$. intraradices, and more specifically in the rhizosphere and mycosphere compartments where the mycorrhizal fungus was allowed to grow and extend from the seedling compartment (Table 2). These results not only reflected the length of $G$. intraradices hyphae but as well the length of hyphae of other soil-inhabiting fungi, which were also measured from bulk soil compartments and control treatments. In these cases, the values were similar and did not vary with mycorrhizal or pathogen inoculation indicating that the soil fungal microflora other than $G$. intraradices was homogeneously distributed among all soil compartments (Table 2).

\section{DISCUSSION}

Root rot symptoms and amounts of genomic DNA of $F$. solani $\mathrm{f}$. sp. phaseoli were significantly reduced in bean plants and in all soil compartments of mycorrhizal colonized plants. These results indicate that $G$. intraradices induced changes that protected the plant against Fusarium root rot and reconfirmed, similar to what previous studies have shown, that arbuscular mycorrhizal fungi may contribute to protection of plants against soilborne pathogens $(9,11,44)$. As our main goal was not to monitor the progression of the disease over time, but instead to improve our understanding of this interaction, it remains clear that time-scale studies following disease progression will also have to be performed before assessing the biocontrol potential of $G$. intraradices against Fusarium root rot under natural conditions.

In this study, both molecular and cultivation-dependant approaches successfully detected $F$. solani f. sp. phaseoli in a soilbased substrate. However, high variability was obtained with $\mathrm{CFU}$ number when estimating $F$. solani f. sp. phaseoli population, a situation also common to different fungal species when using CFU (12,31). We were not able to correlate CFU number and realtime PCR data. This situation could be attributed to the variation

TABLE 2. Effect of Glomus intraradices and Fusarium solani f. sp. phaseoli inoculation treatments on fungal hyphal length and $F$. solani f. sp. phaseoli CFU present in the soil compartments

\begin{tabular}{|c|c|c|c|}
\hline Treatment $^{\mathrm{y}}$ & Compartment & $\begin{array}{l}\text { Hyphal length } \\
\text { ( } \mathrm{m} \mathrm{g}^{-1} \text { of soil) }\end{array}$ & $\begin{array}{c}\text { F. solani } \mathrm{f} \text {. sp. phaseoli } \\
\text { CFU (number of colonies } \times \\
1,000 \mathrm{~g}^{-1} \text { of soil) }\end{array}$ \\
\hline \multirow[t]{3}{*}{ Glo+ Fus+ } & Rhizosphere & $4.95 \pm 0.98 \mathrm{a}^{\mathrm{z}}$ & $2.52 \pm 0.36 \mathrm{a}$ \\
\hline & Mycosphere & $9.11 \pm 2.18 \mathrm{a}$ & $3.12 \pm 0.55 \mathrm{a}$ \\
\hline & Bulk soil & $1.69 \pm 1.28 \mathrm{~b}$ & $2.79 \pm 0.16 \mathrm{a}$ \\
\hline \multirow[t]{3}{*}{ Glo+ Fus- } & Rhizosphere & $5.51 \pm 0.92 \mathrm{a}$ & $\ldots$ \\
\hline & Mycosphere & $5.40 \pm 0.70 \mathrm{a}$ & \\
\hline & Bulk soil & $1.69 \pm 0.00 \mathrm{~b}$ & \\
\hline \multirow[t]{3}{*}{ Glo- Fus+ } & Rhizosphere & $1.24 \pm 0.11 \mathrm{~b}$ & $1.95 \pm 0.36 \mathrm{a}$ \\
\hline & Mycosphere & $1.46 \pm 0.24 b$ & $4.39 \pm 0.22 \mathrm{a}$ \\
\hline & Bulk soil & $1.24 \pm 0.23 b$ & $2.34 \pm 0.58 \mathrm{a}$ \\
\hline \multirow[t]{3}{*}{ Glo- Fus- } & Rhizosphere & $1.24 \pm 0.11 \mathrm{~b}$ & $\ldots$ \\
\hline & Mycosphere & $1.69 \pm 0.59 \mathrm{~b}$ & $\ldots$ \\
\hline & Bulk soil & $1.69 \pm 0.34 \mathrm{~b}$ & $\ldots$ \\
\hline
\end{tabular}

y Glo+ Fus+ = inoculated with $G$. intraradices and $F$. solani f. sp. phaseoli; Glo+ Fus- = inoculated with $G$. intraradices only; Glo- Fus+ = inoculated with $F$. solani f. sp. phaseoli only; and Glo- Fus- = uninoculated controls.

${ }^{\mathrm{z}}$ Values are the means of three replicates \pm standard error of the mean. Values followed by a different letter $(\mathrm{a}, \mathrm{b})$ within columns (treatments) are significantly different using Tukey's studentized range test $(P<0.05)$. 
in mechanical strength applied to dislodge and break Fusarium propagules from soil for subsequent CFU enumeration. In our study, results from real-time PCR were reproducible and clearly showed a statistical trend consistent with symptoms expression on the plants that was not possible to point out with CFU. To the best of our knowledge, this is the first reported study investigating the interaction between different fungal species under a soil environment using real-time PCR quantification.

The use of the compartmentalized microcosm experimental system (15) allowed us to demonstrate that direct interactions between the symbiont and the pathogen or improved mycorrhizal nutritional status of the mycorrhizal plant $(10,19,41)$ are not likely the mechanisms that have played a role in the $G$. intraradices $F$. solani $\mathrm{f}$. sp. phaseoli interaction described here. This is substantiated by the following results: (i) shoot dry weight was not modified as a result of mycorrhizal inoculation or pathogenic infection, indicating that the plant's nutritional status was not significantly improved by mycorrhization; (ii) amounts of $F$. solani $\mathrm{f}$. sp. phaseoli genomic DNA were not different, but equally reduced in all three mycorrhizospheric compartments of mycorrhizal treatments, indicating that no direct interaction between the symbiont and the pathogen occurred in the mycosphere compartment; and (iii) amounts of $G$. intraradices genomic DNA and fungal hyphal lengths were not modified by the presence of $F$. solani $\mathrm{f}$. sp. phaseoli in mycosphere and rhizosphere compartments, a clear indication that the pathogen and the symbiont did not mutually compete for the same resources in the soil, and if they did, the interaction was not significant. In the plant tissues, the reduction in $F$. solani $\mathrm{f}$. sp. phaseoli was associated with a slight but significant increased colonization by $G$. intraradices. These results indicate that direct competition for infection sites, as suggested by several studies $(3,35,44)$ is also unlikely to have operated here.

In light of our results, we propose that an indirect biotic (modification of the soil microflora) and/or abiotic (modification of the physical or chemical soil properties) alteration of the mycorrhizosphere induced by colonization of roots with $G$. intraradices is most likely involved in the reduction of $F$. solani f. sp. phaseoli population in the soil which consequently might have decreased the presence of the pathogen in the plant. Among abiotic and biotic factors potentially responsible for the results obtained, $\mathrm{pH}$, soil chemical composition, root exudation, and soil microflora have all been shown to be altered in response to mycorrhizal colonization in different plant-AMF systems $(1,2,4,5,38,39,48)$.

\section{ACKNOWLEDGMENTS}

This work was supported by FCAR-IRDA and NSERC grants to S. H. Jabaji-Hare and M. St-Arnaud. Financial assistance to M. Filion was supported by an FCAR-Industrial Postgraduate Scholarship in collaboration with Premier Tech Ltée. (Rivière-du-Loup, Québec, Canada). We thank K. O'Donnell (National Center for Agricultural Utilization Research, Agricultural Research Service, USDA, Peoria, IL) for providing us with Effp-1 and Effp-2 sequences, B. Duval for technical assistance, and S. Daigle and G. Taylor for technical advice.

\section{LITERATURE CITED}

1. Andrade, G., Linderman, R. G., and Bethlenfalvay, G. J. 1998. Bacterial associations with the mycorrhizosphere and hyphosphere of the arbuscular mycorrhizal fungus Glomus mosseae. Plant Soil 202:79-87.

2. Andrade, G., Mihara, K. L., Linderman, R. G., and Bethlenfalvay, G. J. 1997. Bacteria from rhizosphere and hyphosphere soils of different arbuscular-mycorrhizal fungi. Plant Soil 192:71-79.

3. Azcón-Aguilar, C., and Barea, J. M. 1996. Arbuscular mycorrhizas and biological control of soil-borne plant pathogens-An overview of the mechanisms involved. Mycorrhiza 6:457-464.

4. Bago, B., Vierheilig, H., Piché, Y., and Azcón-Aguilar, C. 1996. Nitrate depletion and $\mathrm{pH}$ changes induced by the extraradical mycelium of the arbuscular mycorrhizal fungus Glomus intraradices grown in monoxenic culture. New Phytol. 133:273-280.

5. Bansal, M., and Mukerji, K. G. 1994. Positive correlation between
VAM-induced changes in root exudation and mycorrhizosphere mycoflora. Mycorrhiza 5:39-44.

6. Burke, D. W., and Hall, R. 1991. Fusarium root rot. Pages 9-10 in: Compendium of Bean Diseases. R. Hall, ed. The American Phytopathological Society, St. Paul, MN.

7. Caron, M., Fortin, J. A., and Richard, C. 1986. Effect of Glomus intraradices on the infection by Fusarium oxysporum f. sp. radicis-lycopersici on tomatoes over a twelve-week period. Can. J. Bot. 64:552-556.

8. Cordier, C., Gianinazzi, S., and Gianinazzi-Pearson, V. 1996. Colonisation patterns of root tissues by Phytophthora nicotianae var. parasitica related to reduced disease in mycorrhizal tomato. Plant Soil 185:223232.

9. Datnoff, L. E., Nemec, S., and Pernezny, K. 1995. Biological control of Fusarium crown and root rot of tomato in Florida using Trichoderma harzianum and Glomus intraradices. Biol. Control 5:427-431.

10. Davis, R. M., and Menge, J. A. 1980. Influence of Glomus fasciculatus and soil phosphorus on Phytophtora root rot of citrus. Phytopathology 70:447-452.

11. Dehne, H. W. 1982. Interaction between vesicular-arbuscular mycorrhizal fungi and plant pathogens. Phytopathology 72:1115-1119.

12. Dewey, F. M., Thornton, C. R., and Gilligan, C. A. 1997. Use of monoclonal antibodies to detect, quantify and visualize fungi in soils. Adv. Bot. Res. 24:275-308.

13. Doner, L. W., and Bécard, G. 1991. Solubilization of gellan gels by chelation of cations. Biotechniques 5:25-28.

14. Filion, M., St-Arnaud, M., and Fortin, J. A. 1999. Direct interaction between the arbuscular mycorrhizal fungus Glomus intraradices and different rhizosphere microorganisms. New Phytol. 141:525-533.

15. Filion, M., St-Arnaud, M., Guillon, C., Hamel, C., and Jabaji-Hare, S. H. 2001. Suitability of Glomus intraradices in vitro-produced spores and root segment inoculum for the establishment of a mycorrhizosphere in an experimental microcosm. Can. J. Bot. 79:879-885.

16. Filion, M., St-Arnaud, M., Hamel, C., and Jabaji-Hare, S. H. 2001. Use of real-time PCR to study microbial interactions in non-sterile soil. (Abstr.) Phytopathology 91(suppl.):S28.

17. Giovannetti, M., and Mosse, B. 1980. An evaluation of techniques for measuring vesicular arbuscular mycorrhizal infection in roots. New Phytol. 84:489-500.

18. Gonçalves, E. J., Muchovej, J. J., and Muchovej, R. M. C. 1991. Effect of kind and method of fungicidal treatment of bean seed on infections by the VA-mycorrhizal fungus Glomus macrocarpum and by the pathogenic fungus Fusarium solani. Plant Soil 132:41-46.

19. Graham, J. H. 2001. What do root pathogens see in mycorrhizas? New Phytol. 149:357-359.

20. Hall, R. 1981. Correction: Benomyl increases the selectivity of the NashSnyder medium for Fusarium solani f. sp. phaseoli. Can. J. Plant Pathol. 3:97-102.

21. Hassan Dar, G. H., Zargar, M. Y., and Beigh, G. M. 1997. Biocontrol of Fusarium root rot in the common bean (Phaseolus vulgaris L.) by using symbiotic Glomus mosseae and Rhizobium leguminosarum. Microbiol. Ecol. 34:74-80.

22. Hwang, S. F., Chang, K. F., and Chakravarty, P. 1992. Effects of vesicular-arbuscular mycorrhizal fungi on the development of Verticillium and Fusarium wilts of Alfalfa. Plant Dis. 76:239-243.

23. Jakobsen, I., Abbott, L. K., and Robson, A. D. 1992. External hyphae of vesicular-arbuscular mycorrhizal fungi associated with Trifolium subterraneum L. 1. Spread of hyphae and phosphorus inflow into roots. New Phytol. 120:371-380.

24. Joseph, P. J., and Sivaprasad, P. 2000. The potential of arbuscular mycorrhizal associations for biocontrol of soil-born diseases. Pages 139153 in: Biocontrol Potential and Its Exploitation in Sustainable Agriculture. Vol. 1, Crop Diseases, Weeds, and Nematodes. R. K. Upadhyay, K. G. Mukerji, and B. P. Chamola, eds. Kluwer Academic/Plenum Publishers, New York.

25. Kormanik, P. P., and McGraw, A. C. 1982. Quantification of vesiculararbuscular mycorrhizae in plant roots. Pages 37-45 in: Methods and Principles of Mycorrhizal Research. N. C. Schenck, ed. The American Phytopathological Society, St. Paul, MN.

26. Lee, S. B., and Taylor, J. W. 1990. Isolation of DNA from fungal mycelial and single spores. Pages 283-287 in: PCR Protocols: A Guide to Methods and Applications. M. A. Innis, D. H. Gelfand, J. J. Sninsky, and T. J. White, eds. Academic Press, New York.

27. Lehmann, E. 1975. Nonparametrics-statistical methods based on ranks. Holden-Day, Oakland, CA.

28. Linderman, R. G. 1988. Mycorrhizal interactions with the rhizosphere micoflora: The mycorrhizosphere effect. Phytopathology 78:366-370.

29. Linderman, R. G. 1992. Vesicular-arbuscular mycorrhizae and soil microbial interactions. Pages 45-70 in: Mycorrhizae in Sustainable Agriculture. G. J. Bethlenfalvay and R. G. Linderman, eds. Publication 
No. 54, American Society of Agronomy, Madison, WI.

30. Liu, R. J. 1995. Effect of vesicular-arbuscular mycorrhizal fungi on Verticillium wilt of cotton. Mycorrhiza 5:293-297.

31. Mauchline, T. H., Kerry, B. R., and Hirsch, P. R. 2002. Quantification in soil and the rhizosphere of the nematophagous fungus Verticillium chlamydospotium by competitive PCR and comparison with selective plating. Appl. Environ. Microbiol. 68:1846-1853.

32. Mcallister, C. B., Garcia-Romera, I., Godeas, A., and Ocampo, J. A. 1994. Interactions between Trichoderma koningii, Fusarium solani and Glomus mosseae-Effects on plant growth, arbuscular mycorrhizas and the saprophyte inoculants. Soil Biol. Biochem. 26:1363-1367.

33. McFadden, W., Hall, R., and Phillips, L. G. 1989. Relation of initial inoculum density to severity of fusarium root rot of white bean in commercial fields. Can. J. Plant Pathol. 11:122-126.

34. Miller, D. E., and Burke, D. W. 1977. Effect of temporary excessive wetting on soil aeration and Fusarium root rot of beans. Plant Dis. Rep. 61:175-179.

35. Muchovej, J. J., Muchovej, R. M. C., and Gonçalves, E. J. 1991. Effect of kind and method of fungicidal treatment of bean seed on infections by the VA-mycorrhizal fungus Glomus macrocarpum and by the pathogenic fungus Fusarium solani. Plant Soil 132:47-51.

36. Nelson, P. E., Toussoun, T. A., and Cook, R. J. 1981. Fusarium: Diseases, biology, and taxonomy. The Pennsylvania State University Press, University Park.

37. Newman, E. I. 1966. A method of estimating the total length of root in a sample. J. Appl. Ecol. 3:139-145.

38. Olsson, P. A., Baath, E., Jakobsen, I., and Soderstrom, B. 1996. Soil bacteria respond to presence of roots but not to mycelium of arbuscular mycorrhizal fungi. Soil Biol. Biochem. 28:463-470.

39. Schwab, S. M., Leonard, R. T., and Menge, J. A. 1984. Quantitative and qualitative comparison of root exsudates of mycorrhizal and nonmycorrhizal plant species. Can. J. Bot. 62:1227-1231.

40. Slezack, S., Dumas-Gaudot, E., Paynot, M., and Gianinazzi, S. 2000. Is a fully established arbuscular mycorrhizal symbiosis required for bioprotection of Pisum sativum roots against Aphanomyces euteiches? Mol. Plant-Microbe Interact. 13:238-241.

41. Smith, G. S. 1988. The role of phosphorus nutrition in interactions of vesicular-arbuscular mycorrhizal fungi with soilborne nematodes and fungi. Phytopathology 78:371-374.

42. Smith, S. E., and Read, D. J. 1997. Mycorrhizal Symbiosis. 2nd ed. Academic Press, Cambridge.

43. St-Arnaud, M., Hamel, C., Caron, M., and Fortin, J. A. 1994. Inhibition of Pythium ultimum in roots and growth substrate of mycorrhizal Tagetes patula colonized with Glomus intraradices. Can. J. Plant Pathol. 16:187194.

44. St-Arnaud, M., Hamel, C., Caron, M., and Fortin, J. A. 1995. Endomycorhizes VA et sensibilité des plantes aux maladies: Synthèse de la littérature et mécanismes d'interaction potentiels. Pages 51-87 in: La Symbiose Mycorhizienne-état des Connaissances. Orbis Publishing, Frelighsburg.

45. St-Arnaud, M., Hamel, C., Vimard, B., Caron, M., and Fortin, J. A. 1996. Enhanced hyphal growth and spore production of the arbuscular mycorrhizal fungus Glomus intraradices in an in vitro system in the absence of host roots. Mycol. Res. 100:328-332.

46. St-Arnaud, M., Hamel, C., Vimard, B., Caron, M., and Fortin, J. A. 1997. Inhibition of Fusarium oxysporum f. sp. dianthi in the non-VAM species Dianthus caryophyllus by co-culture with Tagetes patula companion plants colonized by Glomus intraradices. Can. J. Bot. 75:998-1005.

47. White, T. J., Bruns, T., Lee, S., and Taylor, J. 1990. Amplification and direct sequencing of fungal ribosomal RNA genes for phylogenetics. Pages 315-322 in: PCR protocols: A Guide to Methods and Applications. M. A. Innis, D. H. Gelfand, J. J. Sninsky, and T. J. White, eds. Academic Press, San Diego.

48. Wright, S. F., and Upadhyaya, A. 1996. Extraction of an abundant and unusual protein from soil and comparison with hyphal protein of arbuscular mycorrhizal fungi. Soil Sci. 161:575-586. 